\title{
INTEGRATING NEW LITERACIES IN AN ONLINE LEARNING COMMUNITY
}

\author{
Sylvia Harkins \\ College of Education, Grand Canyon University (USA)
}

\begin{abstract}
The current developments in information technology have revolutionized the learning practices in education. There have been numerous discussions of how to integrate the new literacies in the online learning community. As technology continues to enhance, it is expected that learning institutions will adopt new scholarship making the traditional ones obsolete. People have drastically adjusted to the modern lifestyle; whereby new forms of communication and information continue to expand. For instance, the use of presentation software, video editors, and social networks has become a key aspect of the disclosure. To this end, learners have to be prepared and proficient enough to embrace these changes. On the contrary, opponents of this ideology argue that the deictic feature of the internet and information communication technology (ICT) might end up impeding learning. Despite these criticisms, there is abundant literature supporting the adoption of digital literacies in the online learning community since it facilitates the expansion of critical thinking and social interaction skills. Numerous advantages have been linked with digital literacies in the modern world. Nonetheless, the existing gap between the new literacies and traditional literacies has led to a slow transition in the learning practices. Instructors are not confident enough that students will adjust effectively to the modern scholarship with the total abolition of the traditional learning practices. What is the efficiency of digital literacies in an online community learning? How will instructors incorporate these procedures in the online classes?
\end{abstract}

Keywords: New literacies, information communication technology (ICT), digital literacies, online learning, and social network.

\section{Introduction}

The internet has become the primary definition of technology for both literacy and learning, whereby the majority of the people are expected to be online in the next two decades. Getting engaged in the new literacies of technology is very crucial for successful engagement in the learning-teaching process. As new ways of communication continue to emerge, learning and teaching strategies are also changing. It is no longer the traditional literacy of paper, chalk, and pencil, but rather learning is taking place through videos, editors' presentations, Skype, blogs, bulletin boards, social networking sites, and Google, among others. Many people are now required to keep at pace with the successive literacies that are necessary to engage with the current technologies effectively.

\section{New literacies in higher education}

Despite the urgency of a new literacy, traditional educational practices have remained in higher education. Very few courses integrate new literacy or technology, such as learning through various social networking sites. The importance of the new literacy is not realized, yet the courses with literacy and ICTs are going to be essential factors in engaging in online age education in higher learning. This study aims to evaluate the importance of integrating new literacies in higher education (Collins \& Halverson, 2018).

\section{Advanced technology}

Advanced technology has extended the notions of literacy that goes beyond the print-based texts to digital texts and the practices related to using them. The innovations have made learning, reading, and writing only in higher education. Unfortunately, most higher learning classrooms are not necessarily 
responsive to the new ways of literacies. According to Coffey (2017), because of many reasons, like not having enough access to technology; understanding and adapting technology has become a barrier to integrating the new literacies. Understanding and integration of technology is required in the lecture halls, like having hands-on experience with technology and applying their learning in teaching. The new literacies consist of new skills as well as methods of literacy that have been made easy and possible by the technological innovations (Miller, 2015).

Tyner (2014) investigated how teachers in the graduate course were supported to use technology and apply new literacies in the classroom as part of their course. They taught student teachers who had enrolled in summer writing camp, and they were observed if they applied technology in their teaching during their teaching practice. Miller (2015) asserts that most of the teachers used technology in teaching reading and writing skills. However, it was noted that some teachers integrated technology in the final years of their course and that was one of the reasons why most of the educators do not emphasize the integration of new literacies. Baran (2014) advocates the expansion and integration of new literacies, which acknowledges advances in technology to make teaching-learning easy and exciting. The new literacies should be used as the new framework to broaden the understanding of literacy in higher learning.

The new literacies are also known as the 21st-century literacies that consist of proficiency with digital tools and ability to collaborate, design, navigate, evaluate, and create multimedia texts (Gallardo-Echenique et al., 2015). These new literacies focus on the way literacy has been transformed with the help of computers and the internet. In the modern digital world, people can create texts with sounds, movement, as well as images. Besides, they control design elements by shaping the size, appearance, as well as the functions and make writing publicly available when one clicks the button. This means that being part of the digital literature involves being able to use digital tools for different reasons. The new literacies are now used in forums like webpages, blogs, and Facebook, among others (Leu et al., 2015).

\section{Collaborate, critical thinking, and problem solving}

New literacies emphasize the ability to collaborate, think critically, as well as solve a problem. Therefore, the lectures should go beyond the traditional technology but focus on enhancing their literacy instruction in higher learning so that the teachers can transfer the same in the lower learning levels. The students should be taught how to access, evaluate, synthesize, make decisions, apply, and contribute information taught in class (Coffey, 2017).

Traditional academic practices have led to slow development and integration of new literacies as well as digital technologies in higher education. Kist and Pytash (2015) assert that new literacies are transformative for learning, teaching, as well as researching in the higher level of education faculties. Leu et al. (2017) suggests that all college students should use technology in class, but this has been limited due to convenience or control, but they have not become a context for substantive learning. Integration of new literacies is still a complex endeavor as the students continue to diverge their familiarity with the skills using digital tools. Ford et al. (2015) proposes that integration of ICTs in the learning process in the universities needs intentional differentiation. However, students still have an interest in using greater integration of technologies in their learning, such as through blogging, messaging, social networking, presentations, and RSS feeds. The researchers warn that the students will not move smoothly from the social entertainment technology to learning technologies. Therefore, a lot of emphasis should be placed on the integration of new literacies while they start their courses in higher education (Mohammadyari \& Singh, 2015).

\section{Social media}

Most researchers have focused on the use of Twitter in learning to increase interaction among students and motivate them to support collaborative learning as well as expand the depth of understanding among learners. Twitter also has important applications in higher education, for instance, Collins and Halverson (2018) noted that there are various ways in which Twitter could be used to give instant feedback during teaching and learning processes. They identified that as students tweet the applications in class, they enhance their attention and listening skills to gather enough information that supports the learning process (Kist \& Pytash, 2015). It can also be used to enhance communication between the learner and the instructor. Students at the university can carry out their group discussion through Twitter groups that consist of students from the same class. This saves on time and improves interaction among learners (Mohammadyari \& Singh, 2015). Also noted was that Twitter inspires students to continue discussing the class content after the classes and strengthens their relationship and communication skills. This can help them compare their notes and answer with different groups. 


\section{Conclusion}

Moreover, Miller (2015) reported that Twitter increases the students' critical thinking and enhances a good learning environment for the students. Digital literacies enable students to communicate or carry out their assignments wherever they are without having to go to class. They can discuss the important topic online, read education materials online, and the assignments are marked as well as comments made by their teachers virtually. Miller (2015) emphases that new literacies be integrated with the higher education to enhance the teaching-learning process.

\section{References}

Baran, E. (2014). A review of research on mobile learning in teacher education. Journal of Educational Technology \& Society, 17(4), 17.

Coffey, G. (2017). Literacy and technology: Integrating technology with small group, peer-led discussions of literature. International Electronic Journal of Elementary Education, 4(2), 395-405.

Collins, A., \& Halverson, R. (2018). Rethinking education in the age of technology: The digital revolution and schooling in America. New York, NY: Teachers College Press.

Ford, E., Izumi, B., Lottes, J., \& Richardson, D. (2015). Badge it! A collaborative learning outcomes-based approach to integrating information literacy badges within disciplinary curriculum. Reference Services Review, 43(1), 31-44.

Gallardo-Echenique, E. E., Minelli de Oliveira, J., Marques-Molias, L., \&Esteve-Mon, F. (2015). Digital competence in the knowledge society. MERLOT Journal of Online Learning and Teaching, 11(1)

Kist, W., \&Pytash, K. E. (2015). "I Love to Flip the Pages": Preservice Teachers and New Literacies within a Field Experience. English Education, 47(2), 131.

Leu, D. J., Forzani, E., Rhoads, C., Maykel, C., Kennedy, C., \&Timbrell, N. (2015). The new literacies of online research and comprehension: Rethinking the reading achievement gap. Reading Research Quarterly, 50(1), 37-59.

Leu, D. J., Kinzer, C. K., Coiro, J., Castek, J., \& Henry, L. A. (2017). New literacies: A dual-level theory of the changing nature of literacy, instruction, and assessment. Journal of Education, 197(2), 1-18.

Miller, S. M. (2015). Teacher learning for new times: Repurposing new multimodal literacies and digital-video composing for schools. Handbook of research on teaching literacy through the communicative and visual arts, 2, 441-453.

Mohammadyari, S., \& Singh, H. (2015). Understanding the effect of e-learning on individual performance: The role of digital literacy. Computers \& Education, 82, 11-25.

Tyner, K. (2014). Literacy in a digital world: Teaching and learning in the age of information. Abingdon-on-Thames, UK: Routledge. 